\title{
Political Islam: In Whose Service?
}

\author{
Türkkaya Ataöv ${ }^{*}$
}

\begin{abstract}
The discussions and the events of the Middle East and North Africa have been intensifying around "political Islam" especially since $9 / 11$. That concept evolved into a global issue as well, principally in terms of its relation to great power interests. While some groups, mostly unofficial but influential, regard the Mohammedan creed as the singular solution to virtually all pressing problems, some others suppose that the same concept poses a conflict with the Judeo-Christian world. Some Muslims, on the other hand, credit secularism as a source of mutual tolerance and a basic condition for progress. It was only in Republican Turkey that this Enlightenment value of the French Revolution had become a constitutional principle in the early 20 th century.

Once an inspiring force behind progress and expansion, but later a cause of stagnation and decline, Islam reasserted itself, after the mid1960 s, as a response to failures of secular administrations to solve mounting economic crises. Imperialist powers also supported religious (and minority) groups in their joint dissatisfaction with secular nationalism and the emerging leftism in the wide Muslim periphery. Political Islam may be better understood if assessed together with the ascendancy of Christian and Jewish fundamentalisms.
\end{abstract}

* Türkkaya Ataöv, PhD, is an emeritus professor in the Department of International Relations, Ankara University, Turkey. 
Both Muslim fundamentalism and the leading imperialist powers, irrespective of a degree of conflicts between them, are active actors in the upheavals in the quoted geographical area. However, the popular movements of the masses have democratic agendas for the benefit of the overwhelming majority.

There is an alternative to such assaults against the rights of the downgraded poor. The initial twin cures for the ills driving from fundamentalism and militarism are secularism and democracy. But a "change" requires organized opposition and a democratic conquest of power by or on behalf of the have-nots.

\section{Keywords}

Islamists, religious reaction, fundamentalism, Muslim Brotherhood, terrorism, imperialism, Greater Middle East project, Afghanistan, Egypt, Syria, secularism, democracy. 
Political Islam: In Whose Service?

\section{Introduction}

Especially since the events of $9 / 11$, the image of "political Islam" has occupied the center stage in world politics, constituting since then the axis particularly in the Middle East and North Africa, the discussion of which has been dominating the official chambers in Washington, DC. Some decision-making quarters, which responded to it as if they were at war with Islam, promoted the judgement that Islam was backward and conservative while the Christian West was progressive and democratic. Hence, a "clash of civilizations" is supposed to loom in some future date.

Some other Westerners, on the other hand, welcome it for different reasons. While some confront the clash of civilizations thesis, quite a few public figures welcome the "moderate" variety of political Islam as a strategic partner or an alternative lesser evil. Many Muslims just admire it as the righteous solution to current problems. Some among the latter, the Sunnis in particular, advocate a fulfilling return to the spirit of Prophet Mohammad's time, and others search for slight measures of accommodation to suit present circumstances. Minorities like the Shi'a (Shi'i), the Ahmadis, and the Alawites (Alevis) seek official recognition and public acceptance. Finally, many Muslims consider themselves as Mohammadans by birth but secular in thought and action. For the latter, Islam and all religions are, not only worthy relics of history but also an assemblage of conduct in moral and cultural terms. They believe, however, that needed breakthroughs and progress can come basically from a secular outlook.

This presentation aims to treat these notions with some summary evaluations of different approaches but with an emphasis on secular choice as the shortest cut to advancement and fairness. The latter course is critical of the reemergence of political Islam as 
a form of fundamentalism, and moreover, as an alternative to frustrate secular nationalism as well as leftist thought and action.

In many Muslim societies, however, whether political Islam is in power or not, there exists the distressing contrast between a surplus-capturing minority on the one side and the overwhelming poverty of the majority on the other. Even the spokespersons of political Islam are silent or intolerant towards protests, no matter how peaceful, against such disparities that cause great injustice and misery.

The demands of justice and the logic of progress require, however, not only peaceful outcries of complaints, but a clear vision of a just society and appropriate means of struggle in order to create it. The whole procedure is not an easy matter. If Muslim leadership, whether fundamentalist or secular, does not know where to go and how to proceed towards a fair commonwealth, no road can deliver the masses there. Even if an idiolized aim is theoretically well described, a better world will not drop from the sky. It takes well-suited and well-timed organization, righteous dedication, smart but responsible politics, and finally acquisition of political power backed by the people.

\section{Islam in Vogue}

The Muslim faith does not necessarily lead to violent political Islam. Not only has there been some separation in the distant past between religious and political spheres in the Muslim communities, secular tendencies could also be observed in most newly-independent and overwhelmingly Mohammadan countries. But it was in Turkey that "laicism", an Enlightenment value of the French Revolution, became a constitutional principle in the 1930s, and still is, irrespective of the assaults to eradicate it. In spite of the 
Political Islam: In Whose Service?

groups like the Organization of the Islamic Conference (OIC), the Muslims are not a monolithic world. A drift towards Islamism accelerated as a consequence of the failures of secular nationalism and the leftist alternative in Muslim strongholds like Egypt.

Backwardness or intolerance are neither new, nor restricted only to Islam. It is well-known that the battle of the Catholic Church against science had held back the flowering of knowledge leading to suffering and martyrs. When Christian Europe with its 'witch-burning' popes was sunk in the horrors of the Dark Ages, the Islamic civilization, with its Al-Bait ul-Hikmah (House of Knowledge), observatories, innovations in hygiene and rich libraries, was the intellectual focal point of the world then. After the 16th century, that civilization seemed deprived of the legacy and the capacity to forge ahead. That part of humanity, once the greatest promise of progress, seemed entangled in irrational judgements. ${ }^{1}$ Likewise, Christian massacre of Jews and some others is an appalling tradition of the past, but the 'democracies' now back some despotic rulers whose modernity seems limited, besides the latest car models on display in the parking lots of princes, to the torture instruments supplied by Western firms.

It is also true that the inroads of colonialism into the leading Muslim empires forced their leaders to hold fast to some modernization, at least in governance, armaments, education and law leading to reforms in the army, schools, communications and

\footnotetext{
1 An illustrious case: It was none other than the religious leaders who much delayed the introduction of the printing press into the Ottoman society, on grounds that the first book to be published had to be the Holy Qur'an (or the dictates of Allah) that could not be squashed between made-made machines. Consequently, although the German Johannes Gutenberg's first book (the Bible) had come out in 1455, the Ottoman Ibrahim Müteferrika's 'print number one' (a French dictionary) saw the light 264 years later (1729).
} 
manufacture. ${ }^{2}$ In spite of the absence of organized clergy within Islam, the ulema, or the men who claimed to interpret the Qur'an, issued excommunication fatwas, a self-involved immunity that even Prophet Mohammad had not done. In some Muslim communities, a gathering of nearly illiterates have assigned to themselves a status without possessing adequate knowledge about their otherwise tolerant religion. This was a tendency of the long-standing centers of belief and power that feared the liberating effects of pure knowledge and rooted out the rationalists.

Decolonization had offered the nationalists, Abd el-Nasser in Egypt (1952) and the Ba'th governments first in Damascus (1963) and then (1968) in Baghdad, their chance to influence politics at home and in the region. Nasser, who faced an assassination attempt by an Islamist, had been a popular idol in the eyes of the Arab peoples but neither succeeded in ironing out the economic problems of the country, nor restraining the neighbouring state of Israel. When the National Liberation Front (Front de libération nationale, FLN) of Algeria was fighting for independence, not only the future of this Maghreb country was at stake, but also that of the whole continents of Africa and Europe. After a long and bloody war of liberation, the policy of economic decolonization brought less than it promised. Habib Bourgiba's tactical compromises eventually led to the independence of Tunisia, but Neo-Destour Socialism could not shield the masses against poverty.

The Islamists forwarded their own solutions to economic crises that secular governments had failed to clear up. Imperialist powers also actively promoted religious groups against secular nationalism and the left in the vast Muslim belt. Western

2 But these attempts for renewal, in the Ottoman society since 1839, or during Mohammad Ali's brief rule (1831-48) in Egypt, remained limited with no expectations for over-all rejuvenation. 
Political Islam: In Whose Service?

domination, hostile to Nasserist and Ba'thist (also Iran's Mohammad Mosaddagh) regimes, persisted even after decolonization through support of conservative, undemocratic and repressive governments.

During the Cold War years, the United States considered nationalism in the Third World, even tendencies for Nonalignment, and leftist movements in general and Communism in particular, as threats to its drive for world dominance. This transAtlantic country was assisted in its plan of action by Saudi Arabia, a Muslim country that was always conservative to the core and a believer in Islamic (or rather Sunni) solidarity. All of its kings called for religious unity, even if it undermined Arab nationalism. Although Nasser had become the voice of the Arab masses, he proved himself as ineffectual in a number of fronts. The Muslim World League (Al-Rabitat al-'Alam al-Islami, 1962) and the OIC (1972) provided instruments through which the Saudi and the US governments would endorse a "moderate" political Islam. ${ }^{3}$ The Egyptian Muslim Brotherhood (Al-Ikhwan al-Muslimeen) grew with US and Saudi support, the perceptions of both set on secular regimes in the region. Their attention was focussed on Iran, the two Ba'th governments, Sudan, Afghanistan, Pakistan and Indonesia.

The United States tried several asssassination attempts at Nasser and brought down Prime Minister Mossaddagh, who had nationalized Iran's oil but convicted of betrayal to his country. Although President Dwight D. Eisenhower lost no time in denying US involvement in the installation of the pro-US Shah, the CIA chief in Tehran narrated the whole episode of the engineered

${ }^{3}$ James P. Piscatori, "Islamic Values and National Interest: The Foreign Policy of Saudi Arabia," Islam in Foreign Policy, Adeed Dawisha, ed., Cambridge, Cambridge University Press, 1988, pp. 33-53. 
coup. ${ }^{4}$ When the Washington-backed coup of General Suharto knocked off 300,000 to a million 'leftists' in Indonesia, he was described by the leading Western politicians as a gleam of light in Asia and a most valuable friend. The names of the initial group of about 5,000 Indonesians to be killed were reportedly provided by the US Embassy in Jakarta. Everyone should now agree that Suharto's 31-year authoritarian rule was brutal, corrupt and aggressive. It is also known now that the Taliban and al-Qa'eda owe their initiation to the US armed forces and the CIA. Some operatives who eventually joined both of these radical Islamist organizations were recruited by a school in Brooklyn (NY) and offered military training at a Virginia CIA camp. ${ }^{5}$ It was after 9/11, however, that some Muslim Americans were arrested and imprisoned - without trial. ${ }^{6}$

\section{Fundamentalism in the West}

In the light of what was said above, the assertion that there is a basic clash between Islam and Judeo-Christianity may be described as an over-simplification. The origins, adaptations, deviations and reversals in Islam, in addition to great power manipulations, challenge the arguments of a host of Western writers. Bernard Lewis, a distinguished scholar of politics, underlined the discord between the religious East and the secular

\footnotetext{
${ }^{4}$ Kermit Roosevelt, Countercoup: The Struggle for Control of Iran, New York, McGrew Hill, 1979.

${ }^{5}$ John Pilger, The New Rulers of the World, London, Verso, 2003, p. 156.

6 Türkkaya Ataöv, 9/11: Discrimination in Response, Geneva, The International Organization for the Elimination of Racial Discrimination, 2004.
} 
Political Islam: In Whose Service?

West. ${ }^{7}$ He attempted to answer the following inquiries: Why so many Muslims resent the rest, and why their bitterness will not easily be mollified? Taking Lewis's approach one step further, Samuel P. Huntington argued that the deep cultural differences beween the two would inevitably lead to a conflict, and the dilemma went beyond the decrees of Islamic fundamentalism; it was Islam itself.

Political Islam may be better conceived if judged as a contemporary phenomenon analogous to Christian as well as Jewish (and even Hindu) fundamentalisms. The basic principles of Jewish fundamentalism, ${ }^{9}$ which is practically unknown outside Israel, are restoration and survival of the 'pure' religious community that presumably existed in the distant but romanticized past. Especially the messianic tendency within that concept is the most influential one. Its supporters oppose any withdrawals from conquered territories and cite Jordan, Lebanon, Syria and Kuwait as the land of Israel belonging to Jews only. Believing in the superiority of the Jewish soul and body over those of the nonJews, they also oppose equality for all citizens. Moreover, the world was created, in their opinion, for the sake of the Jews; the rest could only be accessory with a subordinate position. Jewish fundamentalism set in and moved upward as a reaction against the consequences of modernity upon Jews. It is defined as Jewish Orthodoxy based on the Babylonian Talmud, and believed to be valid in our day, to remain so even eternally. It should be noted that the number of Jews influenced by Jewish fundamentalism is

\footnotetext{
7 Bernard Lewis, "The Roots of Muslim Rage," The Atlantic, September 1990, or www.theatlantic.com/magazine/1990/09/the-roots-of-muslimrage.

8 Samuel P. Huntington, The Clash of Civilizations and the Remaking of World Order, New York, Simon and Schuster, 1998.

9 For a history and development of Jewish fundamentalism and an examination of the various strains: Israel Shahak and Norton Mezvinsky, Jewish Fundamentalism in Israel, London, Pluto Press, 1999.
} 
increasing. This Judeocentric approach takes no cognizance of historical development. Those who fear a second Holocaust also estimate that they can conquer the neighbouring Arab lands within a week. In any case, nuclear capability is at the disposal of the Israeli State. Influential rabbis (like Yoseph and Shach) do not even mention the most rudimentary rights of the Palestinians. The secular Jews as well have to take the Jewish historical past very seriously. Jewish fundamentalism represents the hawkish heart of Israeli politics. ${ }^{10}$

Religion has always played an important part in the affairs of American society. However, it is only in the recent decades that the fundamentalist variant of Christianity has come to exert a powerful influence on the US political stage. There has been a dramatic rise of that movement which holds considerable sway

10 Some Jews oppose Jewish fundamentalism and moreover defend Palestinian rights. The American Council for Judaism was one. See: Thomas A. Kolsky, Jews Against Zionism, Philadelphia, Temple University Press, 1990. For the memoirs of the Council's former executive director: Elmer Berger, Memoirs of an Anti-Zionist Jew, Beirut, The Institute for Palestine Studies, 1978. For eleven analytical reflections on Zionism: Roselle Tekiner, Samir Abed-Rabbo and Norton Mezvinsky, eds., AntiZionism, Battleboro, Vermont, Amana Books, 1988. On how the US administration supported and recognized the Zionist accomplishment: Richard Stevens, American Zionism and U.S. Foreign Policy: 1942-1947, New York, Pageant Press, 1962. People and institutions confronting Israel's lobby: Paul Findley, They Dare Speak Out, Westport, Connecticut, Lawrence Hill and Company, 1985. Recent criticism of Zionism motivated reactions from the friends of Israel. For instance: Abraham Foxman's Never Again?, Alan Dershowitz's The Case for Israel, Phyllis Chesler's The New Anti-Semitism, Paul Iganski and Barry Kosmin's A New Anti-Semitism? But to argue that criticism of Israel and hostility to Jews are the same thing is to conflate the Jewish state with the Jewish people. Just as Israel is one thing and Jewry another, anti-Zionism and antiSemitism are independent variables and are separate. See: Brian Klug, "The Myth of the New Anti-Semitism," The Nation, 278/4 (2 February 2004), pp. 23-29. 
Political Islam: In Whose Service?

over the country's South and power of the Republican Party. The American fundamentalists are fervently committed to free market liberal values and to US military adventurism abroad. With an influence that extends to the corridors of power in Washington DC, this mix of religious extremism, unfettered capitalism and military hawkishness may well be a potent threat to world peace. ${ }^{11}$

Jewish, Christian and other fundamentalist movements are intolerant and even carry traces of racism. Identified with a handy but indiscriminate description as 'Arab terrorism', Islamic fundamentalism is anathema in the non-Muslim world.

\section{US Globalization}

A Punjabi Muslim argues, on the other hand, that the "mother of all fundamentalisms is American imperialism", that it has constructed a new enemy: "Islamic terrorism" and that "its [military] bases now cover every continent." 12 Other writers share his view that the White House tries to cover up the deteriorating situation of the economy with the 'security threat' and accompanying wars. It is no exaggeration to assert that the American arms industry, not only guarantees its unending profit, but also chaperones the economy against a crisis bringing to mind the 1929 crash. The Pentagon as marketer of arms is a wellorganized economic agency of the government, just as American diplomats are also weapons salesmen. The slaughter of civilian

\footnotetext{
11 Türkkaya Ataöv, 'Holy' Terror: the Role of Christian Fundamentalists in U.S.led Globalization and War, Penang, Malaysia, Citizens International, 2008. The same text in: Hans Köchler, ed., The "Global War on Terror" and the Question of World Order, Vienna, International Progress Organization, 2008, pp. 139-181.

12 Tariq Ali, The Clash of Fundamentalisms: Crusades, Jihads and Modernity, London, Verso, 2003, p. xiii and 307.
} 
populations, whether Vietnamese, Somalis, Afghanis or Iraqis, has been a component of that country's war action. When the USSR and the Warsaw Pact broke apart, the military-industrial complex needed to hurridly manufacture new conflicts. Islam and Confucianism, one standing for oil and other for Chinese exports, were appropriate choices for the occasion. Eisenhower's early warning on the "military-industrial complex" has become a global phenomenon now, but he could have added some academics and church spokespersons. Apart from state intellectuals like Huntington, Kissinger, Brzezinski and Fukuyama, an army of apologists for neo-colonialism served the contemporary superpower.

\section{The Ascend of Political Islam}

The motivations of militant Islamic movements are not necessarily similar. The Muslim societies have never been monolithic. Virually each group had Muslim or non-Muslim radical favourites. Caliph Ali and his two sons (Hassan and Hussain, all three Shi'a idols), poets Rumi (humanitarian from Konya in Anatolia) and Iqbal (from pre-Partition Lahore), essayists (Indian Muslim) Maududi and (Persian) Shariati, revolutionaries (Latin American) Guevara and (South Asian) Diap or warriors like (Saudi Arab) Osama bin Ladin had followers at different times in various corners of the Muslim world. Moreover, Muslim armies fought against each other rather frequently. Although an independent state comprising Muslims may not necessarily be Islamist at home and abroad, beneath many, if not all, universalist pretensions lies the compulsion to dominate and exploit. Such pretensions may apply to the US brand of democracy, the Soviet base of world revolution or various Islamist claims. Even the forces meant to challenge oppression may themselves become instruments of coercion. Even myths will be introduced and whipped up, before a 
Political Islam: In Whose Service?

confused public, in order to legitimize a camouflaged motivation. For instance, while everywhere the talk of democracy has been devolving into crude capitalism, the spokesmen of Sunni-Wahhabi Islam consider their system as the truly democratic one in the world.

Not only Lewis and Huntington, but also a number of Muslim writers underscore the exclusive culture of Islam, which leaves out the paramount discussion on the very confrontation between the trifling minority governing the globalized capitalist system and the subordinated majority of popular classes. The Islamists, who profit from the legacy of age-old practices such as soup kitchens, alms, inexpensive hostels and elementary health centers, seem unaffected by abounding class differences and the gross discrimination, inequality and ruin such inequalities inevitably cause. Islamist public service is limited to simple charity, but cunningly offers opportunity for indoctrination, and absolutely fails to be a means for the struggle of the majority to eradicate its poverty.

It should be born in mind that in the concrete and irrefutable issues, political Islam is categorically on the side of cold-blooded capitalism and boundless imperialism. It endorses all the requirements of brute capitalism and justifies inequality. The Islamist groups or political parties in the official decision-making bodies have never opposed the undemocratic privileges of the exploitating classes and at no time defended the rights of the havenots via voting. Such preference was the synchronized guideline of the local lords and the leaders of the imperialist world order.

Political Islam, which has always counted on the ruling classes of the leading Islamist states, is in most cases a serviceable ally of imperialism, and events proved that the latter can get its concurrence. Virtually in all cases the comprador bourgeoisies, the 
bourgeoning upper middle classes and those at the receiving end of the globalization drive support full blast both political Islam and imperialist undertakings.

Occasionally, an 'anti-Western' posture may be detected in some Islamic quarters. It helps to conceal collaboration with imperialism, and hence the false image put forth serves both of them. Likewise, criticism of Christianity does not make a Muslim group anti-imperialist; it may rather stand for ethnocentrism or a demonstration of some degree of sovereignty. Considering Iran's stand against US threats, the sensibility of Hamas on the Palestine issue, Hezbullah's opposition in Lebanon and recurring resistance movements in Iraq, one can say that such actions are inconsistent with political Islam's general accommodation with imperialism. However, such exceptions do not make it anti-imperialist in origin and perpetuation.

Islamophobia, aggrandized and advertised by Western elite and its media, constitutes a part of a general plan that deepens the divisions within the potential critics of the established order. It also equips political Islam with an armour that helps to protect its 'anti-imperialist' image. Islamophobia is not the actual antagonism between the West and the rest, that is, between imperialism and its periphery. This confusion serves the racist right of the West and attaches an anti-Western credibility to political Islam - for the benefit of both.

Most followers of political Islam are not only companions of imperialism, but also outright reactionaries. Their behaviour, at times, towards some other religions (such as the Egyptian Copts), or even less numerous sects within the Muslim fold (such as the Shi'a, Alawites and Ahmedis), finally women (who constitute half of humankind) is ultraconservative. The Qur'anic references to 
Political Islam: In Whose Service?

women recognise the importance of the female sex, but also underline, in some verses, men's authority over women. ${ }^{13}$

"One-half of humankind" deserves a few more appraisals. When Western colonialism subdued the Islamic world with its guns, the colonial rulers did not bring with themselves the ideas of Paine or Marx. Women fought, nevertheless, alongside men during Mohammad's time, and later in Turkey's and Algeria's wars of national liberation. ${ }^{14}$ Although several women were elected as prime ministers in Pakistan, Bangladesh and Turkey, a wave of religious fundamentalism swept the world with the disappearance of the socialist world that had been amalgamated with secularism and modernism. The Wahhabi regime is still in control in a Muslim country where women are forbidden to drive a car alone, ${ }^{15}$ the clerics came to power in Iran, the political left was defeated by a US-mujabideen war effort in Afghanistan, and fundamentalist groups rose again in North Africa and Syria. ${ }^{16}$

Fundamentalist movements turned some popular anger into political (and, in some cases, personal) gains. Having dominated intellectual discourse in some Muslim countries, their direction carries risks. Whatever the motivations, authoritative and traditional dogmatism threatens to guide the destiny of Muslims. The risk may be a partial return to a sort of 'Dark Age'. There are adequate examples of sychophants, who, in response to the regime's rhetoric of Islamization, seized the reigns of society,

${ }^{13}$ Ibn Rushd, from Cordoba, was the first Muslim thinker to point out Islam's shortcomings in terms of women. Two books of Qassem Amine, an Arab judge, became pioneering texts of feminism in the Arab world.

${ }^{14}$ Kemalist Turkey granted to women the rights to vote and get elected before France, Italy and Switzerland in Europe did.

${ }^{15}$ On Arab feminist writing: Susan Muaddi Darraj, "Understanding the Other Sister: The Case of Arab Feminism," Montbly Review, 53/10 (Mr. 2002), pp. 15-25.

${ }^{16}$ Some rights of women are also under threat even in the United States. 
including the police and the judiciary, and embarked on Islamizing everything, foremost education and science.

To imagine that the unique solution to all, or to many, of the problems may be found in the religious tradition is too simple and unrealistic. ${ }^{17}$ Moreover, if the Holy Book is the main source, there will probably be less and less tolerance towards criticism. Some Muslim sections tie practically all scientific phenomena known today to the Holy Qur'an, with the concurrent idea that there is no need for secular science to exist in the 'hands of the Pure'.

When the rectors of 17 Arab universities attended a conference in Kuwait (1983), some delegates insisted that pure science was potentially subversive of religious belief and therefore against Islam. The benefits that technology would bring were welcome, but pure science ought to be toned down. Some 'Islamic scientists', not only violated the calls of logic, but also the very broad-minded interpretations of the same faith. They paved the way to claims that they had calculated the speed in Heaven, the composition of the jinns (spirits), or how to extract energy from them. State-supported international conferences do honours to such 'accomplishments', which normally appear in the local scientific journals. ${ }^{18}$ Shaikh Abdul Aziz ibn Baz, the president of Madina University, was given (1982) the King Faisal international award for his book in which he asserted that the sun moved and

17 The Holy Books fail to mention the dilemma between industrial expansion and global warming or the impasse between machine control and employment.

18 A quarterly journal carries articles that propagate 'a new science'. For instance, an article attempts to trace the origin of jinns to methan gas. A member of the energy commission suggested tapping them as a free source of energy and a solution to the country's energy problem. Safdar Jang Rajput, "Dichotomy of Insan and Jinn and Their Destiny," Science and Technology in the Islamic World, $3 / 1$ (Jan.-Mr. 1985), pp. $28 f$. 
Political Islam: In Whose Service?

the earth stayed still. About seventy papers presented to the conference on "Scientific Miracles of the Qur'an and Sunnah", jointly coordinated by the International Islamic University (Islamabad) and the Organization of Scientific Miracles (Mecca), dealt, inter alia, with the following: "Chemical Composition of Milk in Relation to Verse 66 of Surat An-Nahl of the Qur'an", man at high altitude (or cumulonimbus clouds) as described in the Qur'an, "Discussion on Things Known Only to Allah"...A former elected mayor of Istanbul, chosen on the ticket of an Islamist party, then urged praying for rain (namaz-e-istisqa) to fight the drought of water. (Prayers certainly express ardent wishes for rain, but Nature cannot abruptly change its own rules for the sake of a group of pious-looking bearded men.) The mayor specified that such undertakings, tried in the past, should not be abandoned. ${ }^{19}$ Years later (2013), a curtain was hastily put up completely separating female listeners from the male orchestra members during a concert in the same country. Evolutionary biology was a 'dangerous' subject in a number of Muslim countries. Farouk Mohammad Ibrahim was jailed (1990) for teaching Darwinism in the University of Khartoum. ${ }^{20}$ Definition of "literacy" has been altered in some Muslim countries to mean "religious knowledge". The latter is now a criterion for selecting teachers of science. Conventional subjects and textbooks are revised to emphasize Islamic values. Extra marks were once granted to engineering students who had memorized the Qur'an. Nazra, or the reading of the Qur'an, was made a matriculation requirement. More and more conferences are

${ }^{19}$ His assertion would have been convincing only if prayers everywhere in the past, at all times, had indeed brought rain.

${ }^{20}$ On the response of the Arab world to Darwinism: Adelo A. Ziadat, Western Science in the Arab World - The Impact of Darwinism, 1860-1930, London, Macmillan, 1986. John T. Scopes, a US teacher who introduced the theory of evolution to his students one day, was also found guilty (1925) in the 'Monkey Trial' where the prosecutor was William Jennings Bryan, three times Democratic nominee for presidency and once President Woodrow Wilson's Secretary of State. 
organized on various aspects of Islamization. Of course, chadar is imposed on all female students, and all students have to offer (separately assembled according to the gender) zubr (afternoon) prayers during school hours. I was once invited by a Gulf country to give talks on mutually agreed topics, but could address only the males for whom a separate auditorium was reserved...

Although analogous absurdities also flourish among the devotees of all religions, ${ }^{21}$ the breath of fabrications and illusions in the simple folks of the Islamic communities at times horrify the more rational Muslims. Granted that the Muslim countries have also produced outstanding scholars in exact sciences, some of whom are Nobel laureates in physics and mathematics, the number of scientific studies in Israel, barely 7.5 million, is about twice as those in that vast Muslim belt from the Atlantic shores of the Maghreb to the banks of the Indian Ocean. Publications by Muslim authors quoted in Science Citation Index is much below compared to Israel or Brazil. The richest Muslim country is the oilendowed United Arab Emirates with a per capita GNP that exceeds even that of Japan, but with no scholars of its own, only migrant workers lacking full civil rights and occasionally displaying tendencies for political Islam and expelled when trying to form a coherent group of anything. Certain madrasah (religious school) certificates were made equivalent to MA degree during General Zia's rule in Pakistan, and the same now reportedly equals a Ph.D. in Baghdad. The percentage of exports of machinery in total

\footnotetext{
${ }^{21}$ Both Saints Paul and Augustine were convinced that diseases were the work of devils, and some Christian, Hindu and Islamist fundamentalists argue that major discoveries and world events are already 'hinted' in their respective Holy Books. On the other hand, science, which employs not hints but unequivocal language, starts with assumptions, formulates laws based on facts or sufficient amount of data, tests them against experiment and applies them to a wide range of phenomena, believing in the whole process that a theory is falsifiable in principle.
} 
Political Islam: In Whose Service?

Muslim exports is very low, in many Muslim countries close to zero, while it is 65 percent in Japan.

Coexisting with these adversities, political Islam mobilizes popular masses either to protect the faith or its interests. It can gather crowds in the leading squares or receive enough ballots to be voted into office. Not all Muslim countries are accustomed to periodic elections. Hereditary dynasties rule with an iron hand, and thousands of princes head or control all decision-making bodies at all levels. Elections, if constitutionally required, are quite often criticized as rigged or pre-arranged. In case of blessing by the electorate, actual participation in voting and the electoral system have lots of bearing on such support. Abstentions in general elections frequently reach very high proportions. Some of the supporters of political Islam receive a few pounds of potatoes or low-grade (cancerous) coal just before they reach the ballot box. The tax-paying poor majority meets the expenses, many times over, of the ruling few when the winners throw upper crust banquets to celebrate their gains. In addition, state coercion and modern technology might have allowed prearrangements and deceits. Moreover, the left is either prevented from organization or weak on its own.

\section{The Front-Line Muslims}

The front-line Muslim countries are Saudi Arabia, the Gulf shaikhdoms, Pakistan, Afghanistan, Iran, Iraq, Palestine, Egypt, Syria, and Turkey. The Muslim majorities there and in the periphery comprise about one-fifth of all humanity. They all face capitalist imperialism that is outrageously misstated as forthright 'globalization'. What was once declaimed as "monopolies" is now offered as "free market". World domination through such "open door policy" needed in the recent past two world wars and many 
minor ones, some lasting as long long as ten to twenty years. The system favouring the strongest, the hegemonic superpower will rule over the weak or the less powerful ones, exclusively becoming the state respresenting the system as a whole.

The Muslim Brotherhood was created to shut out the path of the secular Wafd Party. The colonial British and the Egyptian King blessed this reinforcement. ${ }^{22}$ The Islamists fortified their roots in appealing to the growing lower middle class which was after political and economic power. That sub-class and its organization challenged a few outmoded relics, some manifestations of the nouveaux riches and (in some cases) army rule that had never stopped being the most powerful associate of the governing elite. The US-supported initiative for the "Islamic Conference" aimed to break the Non-alignment movement of the Asians and the Africans that had started in Bandung (1955). Hamas in Palestine, which attracted the support of those who reacted against injustice, was formerly endured by Israel with the hope that it could weaken the secular and democratic forces of the Palestinian struggle. The Iranian brand was a revolutionary protest against the one-man Shah repression and foreign mastery in a land proud of its some thousands years of accumulated culture. Saudi Arabia and its Gulf well-wishers remained staunch allies of the United States, a posture accentuated after the Soviet presence in Afghanistan and the Shi'a-imprinted Iranian Revolution.

22 Samir Amin considers the British and King Ahmed Fuad as having "literally created" the Muslim Brotherhood. For his comment: "Political Islam in the Service of Imperialism," Monthly Review, New York, 59/7 (December 2007), p. 7. As evident in my own article here, I concur with Samir Amin, then director of the Third World Forum in Dakar (Senegal), in his assessment that political Islam, in the final analysis, serves imperialism. Amin's books include The Liberal Virus, A Life Looking Forward and The World We Wish to See: Revolutionary Objectives in the Twentieth Century. 
Political Islam would have to face much difficulty if the United States had not extended continuous support. The partnership between imperialism and the traditional ruling classes brightened the future of the Wahhabi brand of political Islam, which would have otherwise been confined behind its own borders. It was Islam in Pakistan's case that formed the state from the bulk of India's Muslims and continued to give it meaning. To set up an Islamic state was only a beginning. It was the United States that motivated the mujabideen during the Afghan War, bolstered political Islam even further in neighbouring Pakistan and moreover carried armed radicals into the international stage. Washington and its regional allies (Saudi Arabia and Pakistan) poured money and arms into the training of the Islamist warriors. Osama bin Ladin, later much-publicized, and Shaikh Azam, one of the Hamas founders, were among them. It has been much in the public eye that the United States supplied Stinger anti-aircraft as well as wire-guided anti-tank missiles, long-range sniper rifles and plastic explosives, and trained them in the use of remote control devises and sophisticated timers. The Afghan War brought together recruits from all Muslim lands, united and prepared them for other ventures.

The Afghan War having created a colossal refugee problem, impoverished Muslims searched asylum in neighbouring Pakistan, where their youngsters took shelter in the free schools that brain-washed while training them in the use of arms. This young generation either formed the Afghan Taliban or other Sunni extremists raising havoc in India's Kashmir and in the Shi'i communities of the host-country, Pakistan.

After the Taliban took control (1979) of Kabul, the militias, not only destroyed the irreplaceable Buddhist statues, but also enforced their variety of Islamic 'morality', including veil and 
chadar for women, beards for men and prohibition of movies, music and television. The United States raised no objections to that kind of masquerade, as long as the Taliban agreed on the transfer of Caspian Sea oil and natural gas.

Political Islam rose even more with the spread of Western neo-liberal model. While the leading international banks, such as Chase Manhattan, Citibank, Goldman Sachs and Pride Waterhouse, provided expertise to the banks owned by the oilexporting Arabs, close relations developed between the Islamists and the neo-liberal ideas of Milton Friedman and his enthusiasts at the University of Chicago.

Political Islam, then, is not necessarily the natural corollary of sincere religious beliefs of the people, but a common arrangement of reactionary circles, submissive comprador classes and imperialism. The dormant position of the secular leftist quarters left the arena vacant for the rightist push. Under the circumstances, the Muslim belt was the "first strike" region for the American and European forerunners of international capital seeking global control. The strategically placed Middle East possessed rich oil resources; it was weak enough to assure plain sailing victory; it offered facilities against China, Russia and other potential rivals; and nuclear Israel was an unconditional local ally.

Apart from the predominantly Muslim Turkey that inscribed secularism into its Constitution, only the Ba'th governments in two Arab states (Syria and Iraq) purported to be secular. The minority Alawite government in Damascus, a legacy of the French mandate, had to bet on secularism in a conservative Sunni majority in the country as a whole. The Ba'th Party in Baghdad could not be expected to be neutral between faith and atheism, but it was not a party of Islam. The Ba'th regimes of Hafiz al-Asad and Saddam Hussein were both secular, but 
Political Islam: In Whose Service?

nevertheless rivals. ${ }^{23}$ Especially after Saddam's takeover of the presidency (1979), Iraq projected an Arab, even a Mesopotamian, orientation rather than an Islamic one. Although virtually all public addresses started with a reference to a "Beneveolent and Protective Allah", Baghdad's Arab National Charter (1980) did not mention Islam, not even once. When Iraq's military units began pouring into Iran at the beginning of the war, Saddam was comparing his initial victory to the ancient (637) Battle of Qaddisiya and appealing to the nationalist rather than the religious feeling of his citizens. As well-known, the United States, in pursuit of oil and strategic advantages, proceeded with an attack on Iraq in spite of the reports of the UN chief inspector, stating that there was no conclusive evidence of weapons of mass destruction (WMD). ${ }^{24}$ Bombarding civilian targets and assassinating selected targets such as teachers and doctors, the United States proceeded to destroy the remaining vestiges of Iraq's secularism.

The recent history of Palestine has been one of colonization for the benefit of some people of Jewish origin and the denial of the right to exist to the Muslims and Christians of the same land. While the bulk of the latter was forced to seek refuge elsewhere, the Jewish state converted into the only local nuclear and a racist power. Neither the United States, nor Israel has a right to enjoy a monopoly over the WMDs, whether or not they accuse Iraq and Iran to possess them. The Oslo and Madrid plans and the roadmap drafted by the United States, followed by the "Greater

${ }^{23}$ In 1974, a high-ranking Syrian Ba'th official counseled me to tell the Iraqi leadership that Baghdad ought to accept all party decisions taken in the Damascus headquarters.

${ }^{24}$ Nor any link to Al-Qa'eda. Scott Ritter, Endgame: Solving the Iraq Crisis, New York, Simon and Schuster, 2002. The chief inspector (with whom I spoke in New York and) who was dedicated to the ideals of the United Nations and conducted a series of surprise inspections, resigned on account of repeated interference from the US Government -clearly in violation Article 100 of the UN Charter. 
Middle East" project, wiped out Palestinian rights altogether, but enforced Israel's expansionist plans. One result of this buildup was the electoral victory of Hamas, which came as a response to Israel's brutal colonialism, now more and more resting on discrimination, In addition to the long and high segregation wall, the Palestinians are now ordered to travel in buses separately from the Jews. The rumble of "anti-Semitism" showered on those who oppose such racist crimes is a modus operandi for a blackmail.

There is a pronounced and unconcealed return to Islam in Turkey as well. The Turkish Republic, during the years of Kemal Atatürk (1923-38), had "not renounced Islam, but reviewed it." 25 When Turkey then abolished the caliphate, eradicated the shari' $a$, closed down centers of superstition, and eliminated the reference to Islam in the state religion, most of such steps were throwing away the already dead wood. ${ }^{26}$ The founders of the republic had made Islam what it should be; a matter of private faith. A prominent Indian scholar described the Turkish Revolution initially as a defence of a heritage against foreign interference turning into a revolutionary zeal. ${ }^{27} \mathrm{~A}$ revolt against foreign occupation and aggression became a revolution that engulfed the historical heritage as well. A step-by-step return to religion started with the change of government after the 1950 general election. ${ }^{28}$

25 Still valuable as an insight into the tension between faith and history in the Islamic world: Wilfred Cantwell Smith, Islam in Modern History, Princeton, NJ, Princeton University Press, 1957, p. 161.

26 For instance, The last Ottoman Sultan-Caliph (Mehmet Vahdettin) requested (1922) the occupation commander in Istanbul to carry him to the Island of Malta in a British warship.

27 Mohammad Sadiq, The Turkish Revolution: A Perspective on Ideological Change in Turkey, New Delhi, Macmillan, 1997.

28 That election was hailed by the noted British historian Arnold J. Toynbee with the following assessment: The victory of the (Western) constitutional spirit in the Turkish election of 1950 was a "landmark which may perhaps even signify a turn of the political tide in the world as 
Political Islam: In Whose Service?

An electrical engineer (Necmettin Erbakan) with ultraconservative views founded three Islamist political parties and supported two others. Having uttered once that the Islamists would eventually come to power by the ballot or by force, he became a premier in a coalition government, but was imprisoned a few times, once on account of committing forgery. One of his star protégés (R.T. Erdoğan), briefly a mayor of Istanbul, was also prosecuted for his following public statement (1997): “The minarets are our bayonets, the domes our helmets, the mosques our barracks, and the believers our soldiers!" Later Turkey's prime minister and responsible for the last decade for the introduction of many Islamist measures, he is paving the way for the US-inspired presidential system to replace the parliamentary practice since $1920 .^{29}$

Islamism was promoted, mainly by the blessing of the rural conservatives and their by-products in the suburbs of the big cities, to limit or eradicate the secular philosophy of the republic and also to diminish the growing influence of the left - with Washington's mostly underhanded compliance and even acclaim. ${ }^{30}$ The growth

a whole." Arnold Toynbee, Civilization Trial and the World and the West, New York, Meridian Books, 1958, p. 253. The author's reference to the "landmark" was on account of free elections and the peaceful change of government in a Muslim society.

${ }^{29}$ For my arguments that the presidential and the federative systems do not suit the Turkish scene: Türkkaya Ataöv, Federasyon, Bașkanlık, Yarbaskeanlık, İstanbul, Destek Yayınevi, 2011. Burhan Kuzu, an MP of the ruling Islamist party (AKP) and head of the Constitutional Committee of the Turkish Grand National Assembly (TBMM), maintains, on the other hand, that the US presidential system works very efficiently, that it is tailor-made for Turkish politics and moreover an outstanding "patriot like the present Prime Minister cannot possibly be a dictator" under that system. See: Burhan Kuzu: Her Yönü ile Başkanlı Sistemi, İstanbul, Babıâli Kültür Yayınları, 2011.

${ }^{30}$ For the Turkish case: Fred Halliday, Nation and Religion in the Middle East, London, Saqi Books, 2000, pp. 177-188. 
of the Islamist parties was accompanied by the revival of various Muslim organizations, foremost the tarikats, discouraged or banned during the first two decades of the republic, but now active in politics, business and media. Apart from the lucrative commercial enterprises at home, most of the capital exported from Turkey to the former Soviet Caucasus and Central Asia, where the overwhelming population is Muslim and/or Turkic, belongs to the well-supplied Islamist circles with close connections with the present government in Ankara.

The followers of a prominent Islamist preacher (Fethullah Gülen) from Turkey, living in a comfortable and multi-purpose compound of residences, guest-houses and helpers for the last decade in Pennsylvania (USA), command various tarikats, simple believers, businessmen and press/television networks, are de facto allies, but also sometimes rivals, of the religion-oriented party and government in Turkey.

Islamist publishing houses, funded locally and from abroad, produce books that glorify Islam and print the translations of the leading foreign fundamentalist writers. Consequently, some streets are now dominated by covered women and bearded men. Although the Turkish Islamists generally shunned from mass violence, celebrated journalists (Abdi İpekçi, Uğur Memcu, Çetin Emeç), a lady-senator well-versed in the true teachings of Islam (Bahriye Üçok), university professors (Muammer Aksoy, Cavit Orhan Tütengil, A. Taner Kışlalı, Necip Hablemitoğlu), a prominent trade unionist (Kemâl Türkler), and 37 secular-minded intellectuals attending an Alewite festival in Sivas were murdered. This is far from being a complete list.

In spite of the gradual but steady march towards more Islamism since 1950, highlighted more than ever in the last decade, the choice of at least half of the close to 80 million total 
Political Islam: In Whose Service?

population still favours a secular society. Bus loads of broadminded Alawites from the four corners of the country habitually visit Atatürk's Mausoleum every 10th of November, the date of loss of that republican leader whose unfaltered secular policies had removed Sunni pressure from the shoulders of the non-Sunni millions. Even the bulk of the young generation, whose parents were born after the passing away of the founding father, seems to believe that his egalitarian domestic and independence-oriented foreign policies are relevant today as well.

In the meantime, events of global historical magnitude are taking place all the way from the northern Atlantic edge of Africa to the Muslim shores of the Indian Ocean and the Gulf. A series of mass actions that began in Tunisia spread to Egypt, Libya, Bahrain, Yemen, and Syria. The suicide of Mohammad Bouazzizi, an unemployed university graduate, touched off mass protests in a number of Muslim countries. Initially twenty-three years of corrupt and repressive rule of Tunisia's President Zine al-Abidine Ben Ali came to an end after only four weeks of mass demonstrations. When live ammunition was fired into crowds of citizens, not one word of even urging restraint came from Obama and his Secretary of State Clinton, who considered Ben Ali as the trusted flag-bearer of neoliberalism in North Africa. When he was forced to flee to a Wahhabist monarchy, another autocratic US ally, the US State Department quickly mischaracterized the upheaval in Tunisia as an isolated event. Although some members of the fallen dictator's extended family, former ministers, and preceding heads of his security network have been arrested, it is only the beginning of a much longer struggle to remove the remnants of his regime.

The revolution in Egypt, the most populous of the Arab countries and which also has the largest working class in the region, overthrew President Hosni Mubarak in eighteen days. The struggle of the millions in the street are far from over. Egypt 
travelled a long way from Nasserism to collaboration with imperialism. Its ruling class committed itself to US and Israel decades ago. World reactionary forces, namely the United States, European Union, Israel, and the repressive Gulf monarchies as well as the local rigid, status quo defenders like the fabulously rich ruling class, the repressive army generals and the remainders of the security chain of command are united to reverse or contain the gains of the people. Mubarak's rule relied on a ruthless police state ready to crush any opposition, an army controlled by generals as servants of Western imperialism and Israeli colonialism, and a neoliberal economic policy that ruined the vast majority while integrating the country into an unequal world system. The first elections after Mubarak's fall brought to power a representative (Mohammad Mursi) of the only well-organized political movement, namely the Muslim Brotherhood.

In about a year in office, President Mursi managed to destroy the image of the Islamists in the eyes of many Egyptians. The Islamist organization, mostly undercover during close to 85 years of its existence, had striven for a shari'a state. The religious fervor of no other government, according to the Muslim Brotherhood, could be sound and satisfactory. While the Ikhwan established the Freedom and Justice Party, the Selafist "Call" formed the Nour (Heavenly Light) Party. When the Islamist candidate Mursi won the election, he immediately tried to infiltrate the fellow Islamists into the main state apparatus, including the judiciary and the Ministry of Interior. With a clear disposition to shut the doors to whoever was not a member of his group, Mursi offered a constitution unwelcomed by a wide range of the political groups. While there was not enough food, medicine, education, electricity, and fuel for the common man, he proved to the public that the Islamists were not on the side of the people at large. What he said and what he did were so different that many Egyptians, including some Islamists in addition to political liberals and leftists, 
Political Islam: In Whose Service?

also withdrew their support from him. Alienation from him occurred when first cracks appeared within months after Mursi took office. Substantial segments of citizenry were discontended before the generals moved in.

It was with US support that the military, led by Abdul Fatah al-Sisi, decided to overthrow Mursi. Although Obama chose not to use the word "coup" for the generals' push, it was a military intervention that brought down an elected government. On the other hand, Mursi's removal pleased a sizable portion of the public. The army, or the top-ranking generals, are now in power, not the masses, who demonstrated during the initial weeks of the "Arab Spring" and who have a different agenda. The military junta took over to serve the economic interests of Egypt's ruling class, to support the geo-political plans of US imperialism, and to prevent the further bourgening of the country's working class. The army cannot find jobs for the many unemployed, improve social services, and respect democratic rights. The generals never intended to establish a nation-wide representative administration. The so-called 'coalition' government is a clique of former Mubarak associates, some Islamists, and politicians with connections to the IMF.

The US choice for Egypt is either the remnants of the collaborationist Mubarak regime or subservient political Islam. Both are in the service of structural changes for further privatizations and globalism in the interest of big capital. The threat posed by the awakening of the poor and the working class, supported by the youth, the women, and the petit-bourgeois, has become more menacing than limited reforms for the generals and the United States. World capitalism has united in offering the Egyptians only two alternatives, either the generals or Islamists. This is the strategy of suffocating the Egyptian revolution. People expect higher wages, a reduction in unemployment, health care, 
education and better housing. This is an agenda for radical structural change, and under capitalism, which both the generals and the Islamists endorse, none of these objectives can be realized; they can only get worse. The remnants of the Mubarak regime, capitalists, and the transitional government will fight tooth and nail to save the inherited system and urge the poor to pay the price. It is the poor, and not the Islamists, who can also fight tooth and nail to save the revolution; they are the real democratic alternative to the impasse in Egypt.

The imperialist forces are maneuvering to mold the aftermath of the events in Syria as well. The initial uprising having started not in the big commercial and industrial centers like Damascus or Aleppo, but in three small towns very near to Syria's neighbours, neither the rebels are yet defeated, nor the quick fall of al-Asad is in sight. While the fighting and devastation go on, imperialism is trying to shape the outcome. Some revolutionary movements have already degenerated into a compliant tool of the West. Some ultra-sectarian Islamist forces, backed by the Saudis, Qataris and (to a lesser extent) by Turkey have become a dominant force in some areas. The United States now fears jihadist and alQa'eda forces, sympathetic towards the present government in Turkey as well, to widen their stronghold in Syria. The Syrian arm of the PKK has also become a de facto power along the extended frontier between Turkey and Syria, independent of both but linked to the Barzani circle in Northern Iraq.

The widening of the armed conflict, in addition to Russian, Chinese and Iranian opposition to Western scenarios for intervention, made it difficult for US and Western European powers to exhibit a military muscle in that important Arab country. A repeat of the Libya-type meddling, even a no-fly zone intervention involving bombardment of anti-aircraft positions amidst densely populated regions, seems difficult at the time of 
Political Islam: In Whose Service?

this writing, but nevertheless, one of the options. Bombardment will cost many more deaths than the victims of both sides in Syria. The United States may also be buying time to rouse and comfort some members of the Syrian military brass to mount a coup or install a post-Asad group to its liking dressed up as a semi-civilian interim government. Imperialism will never accept a working class or poor uprising to threaten its power, and Syrian capitalists may abandon Asad in the interest of the bourgeoisie. Imperialism will leave no stone upturned to arrest a people's movement coming from below. In case the Asad regime falls, one tragic outcome may be a partial massacre of the Alawite minority (which was more tolerant than the Orthodox Muslims but) which has been ruling the country, including the Sunni majority, since independence. Only the aftereffects of a class conflict, if it ends with the ascendancy of the poor majority, Muslim and Christian, Sunni or not, may prevent sectarian wars or long feuds between selfappointed fighting groups that substitute themselves as representatives of the masses.

The "Islamic" emphasis in the Iranian Revolution (1979) was clearly a response to the US-backed Shah dictatorship that suppressed opposition in the Majlis, media, universities, and in all walks of life, except the religious circles where resistance necessarily flourished. Otherwise, political Islam in Iran as well shares the liberal principles of the nation's economic life. But the Islamists there oppose the possibility of integrating their country with a global system in which they would be in a subordinate condition. It is Iranian nationalism, proud of its long history and deep-seated culture, that marks the anti-imperialist angle in its foreign policy.

One cannot dismiss from mind that what a mass struggle in Iran brought down was a corrupt and brutal Western favourite. But when an edict demanding women to veil themselves was 
issued, tens of thousands of female citizens initially demonstrated against this conservative step. The US Government did not take issues when women's rights were curtailed, but when Ruhollah Khomaini described the Washington administration as the "Great Satan", the White House turned to its unfriendly neighbour Saddam Hussain and green-lighted the Iran-Iraq War (1980-88), the second longest interstate war of the 20th century, shorter by only two months than the Sino-Japanese armed conflict (!937-45).

While the Pahlavis had emphasized the ancient and preIslamic nature of the Iranian state and underestimated the Shi'i ulama, Article 5 of the post-1979 Constitution defined the country as a Shi'i Islamic republic, and Article 115 debarred non-Shi'is from presidential office. The new republic formally recognized, however, the non-Muslim (dbimmi, zimmi) communities. Islamic Iran is more tolerant than Pahlavi Iran regarding cultural expression.

While the United States, aided by Israel, has been making plans to oust the regime and destroy the country by another 'preventive war', Iran distinguishes itelf as one of the few countries of the Global South to have a national development project around its nuclear capability. Why should not Iran, or any other country, have the right to pursue such capabilities, especially for peaceful purposes? What right do the imperialist states and the Israeli gendarme of the United States in the region have to enjoy such unshared means? The United States is the only country that has actually resorted to the use of atomic weapons and still dismisses a general ban on their use. 
Political Islam: In Whose Service?

\section{Conclusion}

The vast area forthwith referred to as the Greater Middle East, full of strategic raw materials and crucial geographical opportunities, continues now more than ever to be central conflict between the imperialist interests and the rights of the peoples of the world. This does not mean that other regions, Latin America ${ }^{31}$ for instance, is not important. They are part of a comprehensive context, and the Middle East happens to be the 'first strike' area.

The capitalist world is engaged, in one bold step after another, to drown popular movements all the way from Afghanistan to Algeria. Even then, capitalism finds itself in a protracted crisis. Not only the demonstrations in the Arabian Peninsula still continue, resistance against the ruling classes in the strongholds of Europe, like Greece and Spain, carry the ailments of the global capitalism drive, and are also inspired by the "Arab Spring".

There is certainly an alternative to capitalism and to its global assault called imperialism. While the hegemonic state

31 Eduardo Galeano's Las Venas Abiertas de America Latina shows how foreign companies reaped huge profits through their operations in Latin America. Giving an account of about five centuries of history, he analyzes the effects and causes of capitalist underdevelopment in that continent. He explains the politics of the Latin American bourgeoisies and their subservience to foreign powers, particularly the United States, and how they created increasingly unequal societies. It is a leading source for understanding exploitation there and in the rest of the world. English trans.: Eduardo Galeano, Open Veins of Latin America: Five Centuries of the Pillage of a Continent, New York, Monthly Review Press, 1997. Venezuela's Hugo Chávez presented a copy of the English edition to President Obama. A book that searches alternative views in the face of frustrations with neoliberal reforms in Latin America: Duncan Green, Silent Revolution: The Rise and Crisis of Market Economics in Latin America, New York, Monthly Review Press, 2003. 
pretends to export democracy, the dominated peripheries give birth to movements of freedom and equality. Humankind does not wish various fundamentalist versions of deep-seated religions ruling arrogantly their respective parts of the world. Neither do they wish to see self-styled generals mould societies in their own images. Both the fundamentalists and the generals, however, do exist and promote their outlook, sometimes in accord (as in Pakistan) and often in rivalry (as in Egypt).

In respect to the fundamentalists, the whole truth can hardly be found in a single book. Truth or science is like a building that needs perpetual repairs. Further, advancement calls for 'revolutionary science' rather than 'normal science', the latter operating only within the framework of already accepted beliefs. The first step of the remedy is to undermine the politicizing effectiveness of rabble-rousing in contemporary as well as in the history of certain religions.

The initial twin cures for the ills driving from fundamentalism and militarism are secularism and democracy. The antidote to both religious radicalism and noncivil administration is the adoption of laicism as a state policy, or better as a constitutional article. There is still hope if adequate oil funds in the Muslim Gulf states may be made available for science. Since there is one universal science, the assumption of some Muslims that modernity is synonymous with Westernization is false. The Muslim world desperately needs organizations for secular research and inbred scientists along with home-grown technology to be encouraged by the state. Individuals in objective experimentation may be as religious as they wish, but science can only be a secular inquiry. Those who believe in the existence of the Divine have to admit that exact sciences such as chemistry, mathematics and physics recognize no laws outside their own. 
Political Islam: In Whose Service?

The legitimate complaints of the common man, such as a variety of inequalities, are not natural conditions ordained by Allah (or God). Grievances can be met via organized struggle. The upper crusters of the exploiting minority fear the coordinated opposition of the men and women in the street. Social struggles do not need to be violent. The power of a synchronized "No!" of the masses may be more convincing than any other means for change. The majority in question requires a leftist agenda that reflects the much-delayed aspirations of the many. Considering that political Islam has been able to mobilize significant numbers in the past, should one conclude that the secular-minded left should seek alliances with Islamic organizations? Since political Islam has successfully activated large crowds, the left should take this fact into consideration, but should keep in mind that radical Islamic organizations have also terminated that kind of burdensome association, with violence if necessary. Some Muslim administrations have done so in the recent past. In any case, the starting point is the secular option, a leftist agenda and a struggle against imperialism, which is the mother of many malevolence. 